\title{
Distribution Pattern and State of Coenotic Population of Tulipa lehmanniana Merckl. in Kyzylkum Desert Conditions (Uzbekistan)
}

\author{
Ozodbek S. Abduraimov ${ }^{*}$, Habibullo F. Shomurodov', Azizbek S. Abduraimov² \\ ${ }^{1}$ Institute of the Gene Pool of Plants and Animals, Academy of Sciences of Uzbekistan, Tashkent, Uzbekistan \\ ${ }^{2}$ Department of Ecology and Geography, Gulistan State University, Gulistan, Uzbekistan \\ Email: *ozodbek88@bk.ru
}

How to cite this paper: Abduraimov, O.S., Shomurodov, H.F. and Abduraimov, A.S. (2017) Distribution Pattern and State of Coenotic Population of Tulipa lehmanniana Merckl. in Kyzylkum Desert Conditions (Uzbekistan). American Journal of Plant Sciences, 8, 288-296.

http://dx.doi.org/10.4236/ajps.2017.82020

Received: December 22, 2016

Accepted: January 19, 2017

Published: January 22, 2017

Copyright $\odot 2017$ by author(s) and Scientific Research Publishing Inc. This work is licensed under the Creative Commons Attribution International License (CC BY 4.0).

http://creativecommons.org/licenses/by/4.0/

\begin{abstract}
The current state of coenotic populations of rare and endangered species of Uzbekistan-Tulipa lehmanniana Merckl. is given. Within the western part of the area (Kyzylkum desert) in different ecological and phytocenotic conditions, 8 coenotic populations of the species were identified. Based on the number of organism and population traits, the current state of coenotic populations of the species was evaluated. It was revealed that the vast majority of coenopopulations are in pessimal state. Coenopopulation only growing on the eastern part of the mountain Kuljuktau was assessed as optimal.
\end{abstract}

\section{Keywords}

Tulipa lehmanniana, Liliaceae, Kyzylkum, Distribution, Coenotic Population

\section{Introduction}

Tulipa L. genus is represented by 63 species [1] in Central Asia, which is more than $60 \%$ of all species of the Earth (according to various data total amount of species of tulip on the Earth varies from 50 to 100). Such a great variety of species shows a leading position of Central Asia in process of formation of Tulipa genus species diversity. From the 63 species in Uzbekistan 34 are grown, Kazakhstan-37, Kyrgyzstan-22, Tajikistan-24, and in Turkmenistan-16 species. 8 species out of 34 members of the genus occur in Uzbekistan, native to arid habitats, where the amount of annual atmospheric condensation does not exceed 120 - $140 \mathrm{~mm}$ per year. The species are: Tulipa lehmanniana Merckl, T. buhseana Boiss, T. borszczowii Regel, T. sogdiana Bunge, T. biflora Pall, T. sharipowii Tajibaev, T. intermedia Tajibaev, T. micheliana Hoog [2]. 
Tulipa lehmanniana, T. buhseana, T. borszczowii, T. sogdiana and T. biflora are genuine desert species from the aforementioned species. The area of the first two species covers of Turan lowland and reaches to northern China (Kashgar), and the other three species are strict endemic of Turan phyto-geographical region. Two species-recently described from Fergana Valley-Tulipa sharipowii and T. intermedia grow on gray-brown soils of the southern foothills of the $\mathrm{Ku}$ rama Range (Western Tien-Shan) [3]. And finally, the last endemic species of Central Asia-Tulipa micheliana, mainly distributed in the northwest of the Pamir-Alay and Kopetdag, the westernmost border of its range, comes in Kyzylkum (Nurata relict mountains and Kokchatau).

Tulipa lehmanniana, T. sharipowii and T. micheliana are listed in the Red Book of the Republic of Uzbekistan from aforementioned species [4].

The paper presents the results obtained in the last 5 years on assessment of cenotic populations' state of Tulipa lehmanniana.

\section{Materials and Methods}

\subsection{Study Area}

Ecological-phytocenotic and geographical characteristics of the studied coenopopulation is given in Table 1. It should be noted that the vast majority of coenopopulations were highlighted in the south-eastern part of the Kyzyl Kum. Projective cover of grass, which were allocated T. lehmanniana coenopopulations, in most cases amounted to $15 \%-30 \%$. In individual cases it reached 55\% (CP7). Herewith proportion of studied species in the projective covers less than $2 \%$. Studied coenopopulations of $T$. lehmanniana grows within different plant communities, where Artemisia diffusa is dominant or codominant.

Table 1. Characteristics of the studied cenopopulation (CP) of T. lehmanniana in Kyzylkum desert (Uzbekistan).

\begin{tabular}{|c|c|c|c|c|c|c|}
\hline $\begin{array}{l}\mathrm{N}^{\circ} \text { of } \\
\mathrm{CP}\end{array}$ & $\begin{array}{l}\text { Geographical location } \\
\text { of coenopopulation }\end{array}$ & $\begin{array}{l}\text { Geographical } \\
\text { coordination }\end{array}$ & $\begin{array}{l}\text { Altitude, } \\
\text { m }\end{array}$ & Plant community & $\begin{array}{c}\text { Total projective } \\
\text { cover of } \\
\text { vegetation, } \%\end{array}$ & $\begin{array}{c}\text { Projective } \\
\text { cover of } \\
\text { species, \% }\end{array}$ \\
\hline 2 & $\begin{array}{l}\text { Navoi region, Central part of the Kuljuktau, } \\
\text { in the vicinity of the well Sultanbibi }\end{array}$ & $\begin{array}{l}\text { N } 40^{\prime} 45.896^{\prime} \\
\text { E } 064^{\prime} 46.305^{\prime}\end{array}$ & 461 & $\begin{array}{l}\text { Salsola arbuscula-Artemisia } \\
\text { diffusa-Carex physodes }\end{array}$ & $20-25$ & 1 \\
\hline 3 & $\begin{array}{l}\text { Navoi region, South-western Kuljuktau, } \\
\text { not far from the well of Aktashli }\end{array}$ & $\begin{array}{l}\text { N } 40^{\prime} 48.263^{\prime} \\
\text { E } 063^{\prime} 43.976^{\prime}\end{array}$ & 437 & $\begin{array}{l}\text { Artemisia diffusa-Carex } \\
\text { physodes }+ \text { Poa bulbosa }\end{array}$ & $25-30$ & 2 \\
\hline 4 & $\begin{array}{c}\text { Bukhara region, Northerh slopes } \\
\text { of the Eastern Kuljuktau }\end{array}$ & $\begin{array}{l}\text { N40'47.317' } \\
\text { E } 064^{\prime} 02.201^{\prime}\end{array}$ & 573 & Artemisia diffusa + Ferula foetida & $25-30$ & 1 \\
\hline 5 & $\begin{array}{c}\text { Bukhara region, Shafirkan district, } \\
\text { near the village Galaba }\end{array}$ & $\begin{array}{l}\text { N } 40^{\prime} 17.581^{\prime} \\
\text { E } 064 ' 23.430^{\prime}\end{array}$ & 229 & $\begin{array}{l}\text { Haloxylon aphyllum-Ferula } \\
\text { foetida-Artemisia diffusa }\end{array}$ & $15-20$ & 1 \\
\hline 6 & $\begin{array}{l}\text { Navoi region, on the road } \\
\text { Chuntibay-Jongeldi (Kyzylkum) }\end{array}$ & $\begin{array}{l}\text { N } 40^{\prime} 55.919^{\prime} \\
\text { E } 063^{\prime} 32.795^{\prime}\end{array}$ & 334 & Artemisia diffusa-Carex physodes, & $28-30$ & 2 \\
\hline 7 & $\begin{array}{l}\text { Navoi region, on the road } \\
\text { Nurota-Baymurod (Kyzylkum) }\end{array}$ & $\begin{array}{l}\text { N } 40^{\prime} 49.637^{\prime} \\
\text { E } 065^{\prime} 50.373^{\prime}\end{array}$ & 325 & $\begin{array}{l}\text { Haloxylon aphyllum-Artemisia } \\
\text { diffusa + Convolvulus hammadea, }\end{array}$ & $53-55$ & 2 \\
\hline 8 & $\begin{array}{c}\text { Navoi region, on the road } \\
\text { Kazaktau-Toxtatau (Kyzylkum) }\end{array}$ & $\begin{array}{l}\text { N 41'32.060' } \\
\text { E } 064^{\prime} 52.657^{\prime}\end{array}$ & 235 & $\begin{array}{l}\text { Colligonum microcarpum-Ferula } \\
\text { foetida }+ \text { Artemisia diffusa }\end{array}$ & $20-25$ & 2 \\
\hline
\end{tabular}




\subsection{Materials}

Materials for the study of ontogenesis, the structures of populations and coenopopulation state evaluation were gathered in the Uzbek part of the Kyzyl-Kum.

T. lehmanniana is a perennial, herbaceous, polycarpic, bulbous plant. Under natural conditions it grows in foothill belt semisavanna deserts; on sanded hammada and outputs of variegated rocks at altitude of 450 above sea level. In Uzbekistan it is found in foothill deserts of Western Tien Shan and Kyzylkum desert. Outside Uzbekistan it is distributed in Kazakhstan, Turkmenistan, Iran and Afghanistan (the determinant of plants [5], Flora of the USSR [6]).

\subsection{Survey Methods}

To estimate of the coenopopulation state as organismic traits we selected:- reproductive efforts of species (R/E); individual biomass; plant height; length of the leaf; length of the perianth. Density of individuals per $1 \mathrm{~m}^{2}$; ecological density of individuals per $1 \mathrm{~m}^{2}$; the proportion of young individuals fraction (j-v); the proportion of individuals of generative fraction $(\mathrm{g})$; the proportion of individuals of older fraction (s) were taken as the population signs.

To assess of the coenopopulation state a range of selected features are divided into five classes with the same amount on a equable scale; then each class was assigned a score; lowest score corresponded to the lowest indicators (Table 1). The evaluation results are presented in the form of a multi-axis chart.

A structure of populations was studied in standard method [7] [8]. Transects were laid a length of $10 \mathrm{~m}$, they were divided in area for $1 \mathrm{~m}^{2}$. Each coenopopulations laid from 10 to 30 sites over $1 \mathrm{~m}^{2}$. Ontogenetic structure cenopopulation was defined as the ratio in populations of individuals of different developmental states. An individual was taken for the unit of account. At characterization of the population structure based on the idea of the typical ontogenetic spectrum [9]. 4 types of spectra are emphasized by the nature of the ontogenetic groups distribution: left-sided, centered, right-sided and bimodal. The typical range is dependent on the biological characteristics of the species.

Cenopopulations described according to the classification of A.A. Uranov and O.V. Smirnova [10] and "delta-omega" of L.A. Jivotovskiy [11]. Delta $(\Delta)$-an index of population age [7], which assesses the age level of coenopopulations at any moment of time, and omega $(\omega)$-the effectiveness of the plant i-ontogenetic state (the value of "load" on the energetic resources of environment, expressed as a fraction load produced by middle-aged generative condition plants of this population. According to this classification, the $\mathrm{CP}$ can be young, ripening, transition, aging and old.

Population density was determined by the number of individuals or biomass on per unit area or volume. Particular attention was paid to the average density, i.e. the number of per unit whole space or ecological density-the number of per unit habitable space that can actually be occupied by population [12].

Reproductive effort of plants was determined against the weight of generative structures to the total weight of the individual [13]. Assessment of cenopopula- 
tion state carried out using organismic and population characteristics [9]. To this, each characteristic range was divided into five classes with the same volume on an equable scale; then each class was assigned a score; lowest score corresponded to the lowest indicators. The evaluation results are presented in the form of multiaxis diagrams.

Recovery factor of species $\left(\mathrm{I}_{\mathrm{r}}\right)$ was determined by methods of Ishbirdin, Ishmuratova [14].

Geobotanical descriptions were made by standard methods at the sites of 100 $\mathrm{m}^{2}$ [15]. Plant name was given by the latest Cherepanov record [16] (Table 1).

\section{Results and Discussion}

Coenopopulation assessment on organismic signs showed that the maximum reproductive effort (5 points) were found in the ephemeral-ephemeride-wormwood community on the northern slopes in the eastern part of Kuldzhuktau. The high value of reproductive effort (R/E) in this community due to the sufficiency of humidity for desert species. It should be note, that this coenopopulation was studied in the pit-run fines of watershed part of the ridge, where, along with the dominant desert species grow some mountain floral elements. Relatively high humidity and abundant, with respect to the humus, substrate promotes normal growth and development of $T$. lehmanniana individuals. $\mathrm{R} / \mathrm{E}$ of individuals in this region reaches up to $23.3 \%-25.7 \%$. Coenopopulations (CP 1, 2, 3, 8) with a low value R/E confined to gravelly and sandy soils of the southern piedmont plains and along the dry sais (Table 2).

As the value of the reproductive efforts of individuals and the values of other organismic traits (biomass and height of the individuals, the length of the leaves and perianth) high in the $\mathrm{CP} 4$. Average value (4 - 5 points) the length of the pe-

Table 2. Ranking point of T. lehmanniana signs value.

\begin{tabular}{|c|c|c|c|c|c|c|}
\hline \multirow{2}{*}{$\begin{array}{l}\mathrm{N}^{\circ} \text { of } \\
\mathrm{CP}\end{array}$} & \multirow{2}{*}{ Signs } & \multicolumn{5}{|c|}{ Points } \\
\hline & & I & II & III & IV & $\mathrm{V}$ \\
\hline 1 & $\begin{array}{l}\text { Reproductive effort, } \\
\text { (RE), \% }\end{array}$ & $14.1-16.41$ & $16.42-18.73$ & $18.74-21.05$ & $21.06-23.37$ & $23.38-25.7$ \\
\hline 2 & Individual biomass, $\mathrm{g}$ & $9.5-12.17$ & $12.18-14.85$ & $14.86-17.53$ & $17.54-20.21$ & $20.22-22.9$ \\
\hline 3 & Plant height, $\mathrm{mm}$ & $109.4-123.5$ & $123.6-137.7$ & $137.8-151.9$ & $152-166.1$ & $166.2-180.4$ \\
\hline 4 & Leaf length, mm & $87.6-106.5$ & $106.6-125.5$ & $125.6-144.5$ & $144.6-163.5$ & $163.6-182.8$ \\
\hline 5 & Perianth length, $\mathrm{mm}$ & $25.3-28.37$ & $28.38-31.45$ & $31.46-34.53$ & $34.54-37.61$ & $37.62-4.07$ \\
\hline 6 & $\begin{array}{l}\text { The individuals } \\
\text { density of species } \\
\text { per } 1 \mathrm{~m}^{2} \text {, pieces. }\end{array}$ & $4.5-7.57$ & $7.58-10.65$ & $10.66-13.73$ & $13.74-16.81$ & $16.82-19.9$ \\
\hline 7 & $\begin{array}{l}\text { Ecological density } \\
\text { of } 1 \mathrm{~m}^{2} \text {, pieces. }\end{array}$ & $6.42-9.82$ & $9.83-13.23$ & $13.24-16.64$ & $16.65-20.05$ & $20.06-23.5$ \\
\hline 8 & Proportion s, \% & $0-2.45$ & $2.46-4.91$ & $4.92-7.37$ & $7.38-9.83$ & $9.84-12.3$ \\
\hline 9 & Proportion g,\% & $8.5-13.93$ & $13.94-19.37$ & $19.38-24.81$ & $24.82-30.25$ & $30.26-35.7$ \\
\hline 10 & Proportion j - v,\% & $64.1-69.37$ & $69.38-74.65$ & $74.66-79.93$ & $79.94-85.21$ & $85.22-90.5$ \\
\hline
\end{tabular}


rianth noted in the CP 2 and CP 8, in the vicinity of Sultanbibi well and on the way of Kazaktau and Tohtatau relict. In other coenopopulations value of biomass and height of individuals, as well as the length of the leaves and perianth were low (1 - 2 points). The low values of these signs were associated one the one hand with arid habitats, and on the other, with a low humus content in the substrate and overgrazing.

The maximum and high ( 5 and 4 points) value of average density and ecologic density of individuals were marked in 1, 2, $3 \mathrm{CP}$. In these coenopopulation the average density of individuals was $13.65 \mathrm{ind} / \mathrm{m}^{2}-19.9 \mathrm{ind} / \mathrm{m}^{2}$, and density of the environmental-16 ind $/ \mathrm{m}^{2}-23.4 \mathrm{ind} / \mathrm{m}^{2}$, respectively. The maximum and high value of species density in these coenopopulations, probably due to the favorable conditions for seed resumption. Note that the CP 1 grows on the overgrazed areas, where dominated Peganum harmala. Naturally, in such secondary communities due to lack of competition, species of the Tulipa genus, as the reagents on the strategy, occupy large areas. Low levels of these features in the CP 4 were associated with less undergrowth in the community. More favorable on precipitation years, young, immature plant in slopes washed away by ephemeral streams.

In other coenopopulations incidence of individuals in $1 \mathrm{~m}^{2}$ ranged from 4.5 to 12.8, ecological density ranged from 6.42 to 15.05 in per $1 \mathrm{~m}^{2}$ of area. This situation can be directly attributed to the fact that studied coenopopulations located along the road, and gathered by people during flowering (Figure 1).

All investigated coenopopulations were normal, but 5 and 7 coenopopulations were not complete. The maximum and high value of generative and senile individuals (4 - 5) marked in the CP 4. This is due to favorable environmental conditions of habitat. Young fraction was estimated 1 - 2 score. As noted above, the
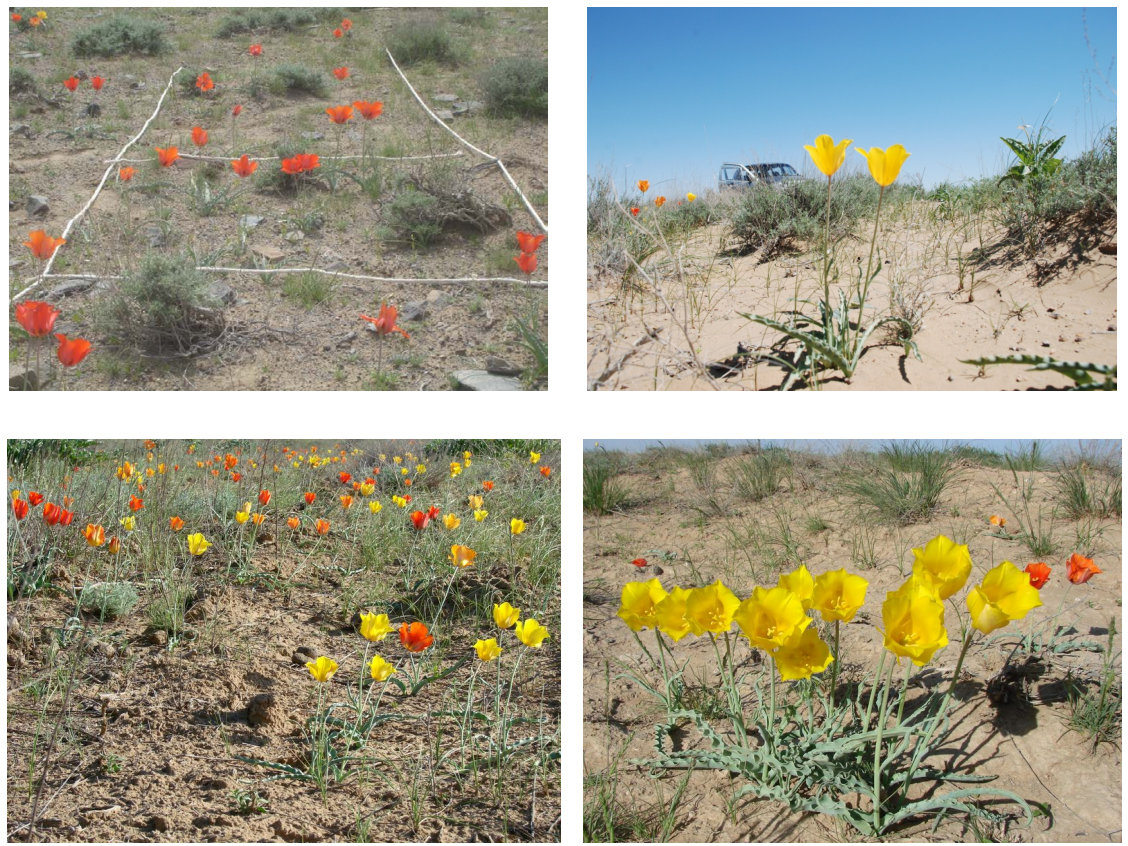

Figure 1. Cenopopulations of Tulipa lehmanniana in Kyzylkum desert (Uzbekistan). 
low number of juveniles at the time of the study-the result of juvenile outburst during spring grads. The maximum value observed in young sand fraction (CP 2 and 6), where the conditions were more favorable for seed growth due to better permeability of precipitation as compared with gypsiferous soil (CP 1) (Figure 2).

Coefficients reflecting individuals age ( $\Delta$-delta) and efficiency ( $\omega$-omega) showed that studied coenopopulations were in juvenile state (Table 3 ).

The ability to rapidly reproduce with seeds and vegetative ways of many Tulipa L. provides the juvenile state of coenopopulation types.

It should be emphasized, that in process of investigation of Tulipa lehmanniana seeds productivity it was observed development of 350 - 550 potential seeds in seed box from one plant. This state plays an important role in the efficiency of the recovery factor on coenopopulation scale. In the course of our studies it has been reported that the ratio of species recovery (Ir) ranged from 1.79 to 10.6. A low level of the recovery coefficient was characterized by individuals plenty in generative coenopopulations. Great number of generative individuals of coenopopulations has a positive impact on the rate type of recovery (Table 3).

\section{Conclusion}

Thus, the diagnosis of T. lehmanniana coenopopulation conditions showed that none of the surveyed coenopopulation noted maximum concurrence of amount of value signs. But on complex of all selected organismic traits and value of generative and old faction share of individuals, a territory, where it grows the fourth cenopopulation can be considered eco-phytocenotic optimum for T. lehmanniana. The low value of the average density and the ecological density of individuals, as well as the share of young fraction in the coenopopulations can be considered as temporary indicators related to weather conditions of research conduct year (Figure 3).

Table 3. Demographic characteristics of T. lehmanniana coenopopulations.

\begin{tabular}{ccccccc}
\hline $\mathrm{N}^{\circ}$ of CP & $\omega$ & $\Delta$ & $\mathrm{I}_{\mathrm{r}}$ & $\begin{array}{c}\text { Individuals } \\
\text { density/m², (pcs) }\end{array}$ & $\begin{array}{c}\mathrm{P}_{\text {ecol }} \\
\left(1 \mathrm{~m}^{2}\right)\end{array}$ & $\begin{array}{c}\text { CP type on } \\
\text { "delta-omega" test }\end{array}$ \\
\hline 1 & 0.38 & 0.18 & 2.89 & 17.65 & 23.5 & Young \\
2 & 0.35 & 0.16 & 3.80 & 19.9 & 23.4 & Young \\
3 & 0.29 & 0.15 & 3.99 & 13.65 & 16 & Young \\
4 & 0.44 & 0.22 & 2.40 & 8.75 & 10.8 & Young \\
5 & 0.51 & 0.22 & 1.79 & 7.7 & 9.6 & Young \\
6 & 0.30 & 0.11 & 10.6 & 12.8 & 15.05 & Young \\
7 & 0.48 & 0.18 & 3.28 & 4.5 & 6.42 & Young \\
8 & 0.38 & 0.26 & 3.29 & 6.65 & 8.86 & Young \\
\hline
\end{tabular}

Note: $\Delta$-age population index; $\omega$-efficiency index; $\mathrm{I}_{\mathrm{r}}$-recovery index; $\mathrm{P}_{\text {ecol }}$-ecol-ecological density of individuals $/ \mathrm{m}^{2}(\mathrm{pc})$. 
CP-1

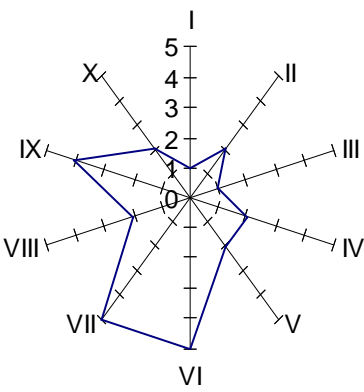

CP-3

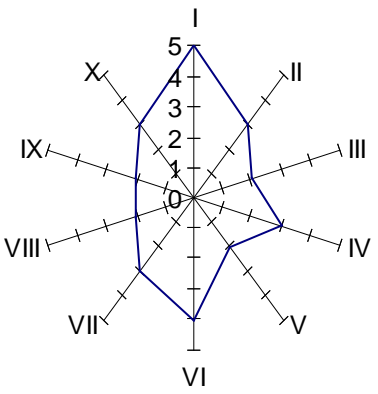

CP-5

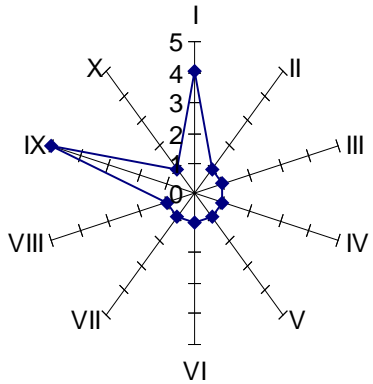

CP-7

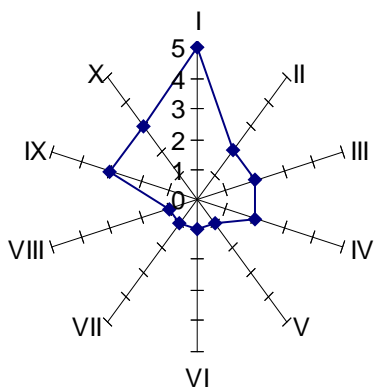

CP-2

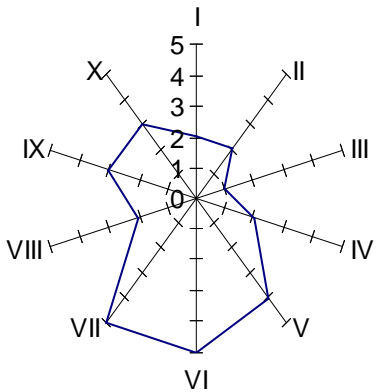

CP-4

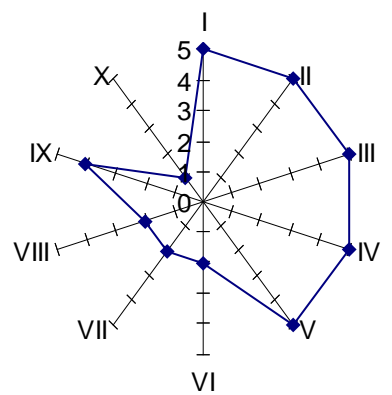

CP-6

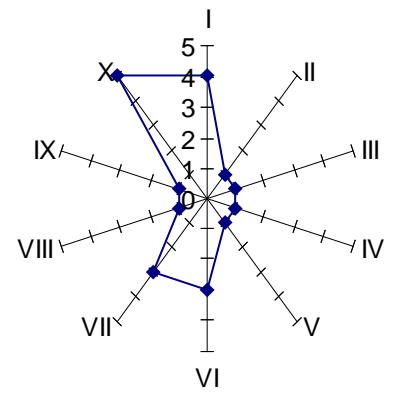

CP-8

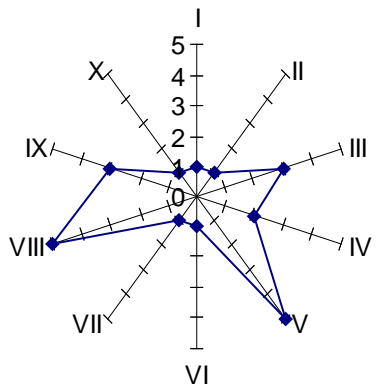

Figure 2. Assessment of T. lehmanniana cenopupulation (in points). Organismic signs: 1-reproductive effort of individuals (R/C); 2-individuals biomass; 3-plant height 4-leaves length; 5-the perianth length; Population characteristics: 6-T. lehmanniana individuals density on $1 \mathrm{~m}^{2}$; 7-ecological density of individuals $/ \mathrm{m}^{2}$ (pcs); 8-the old faction share $(\mathrm{s})$; 9-generative fraction share $(\mathrm{g}) ; 10$ - share of young plants fraction $(\mathrm{j}-\mathrm{v})$. 


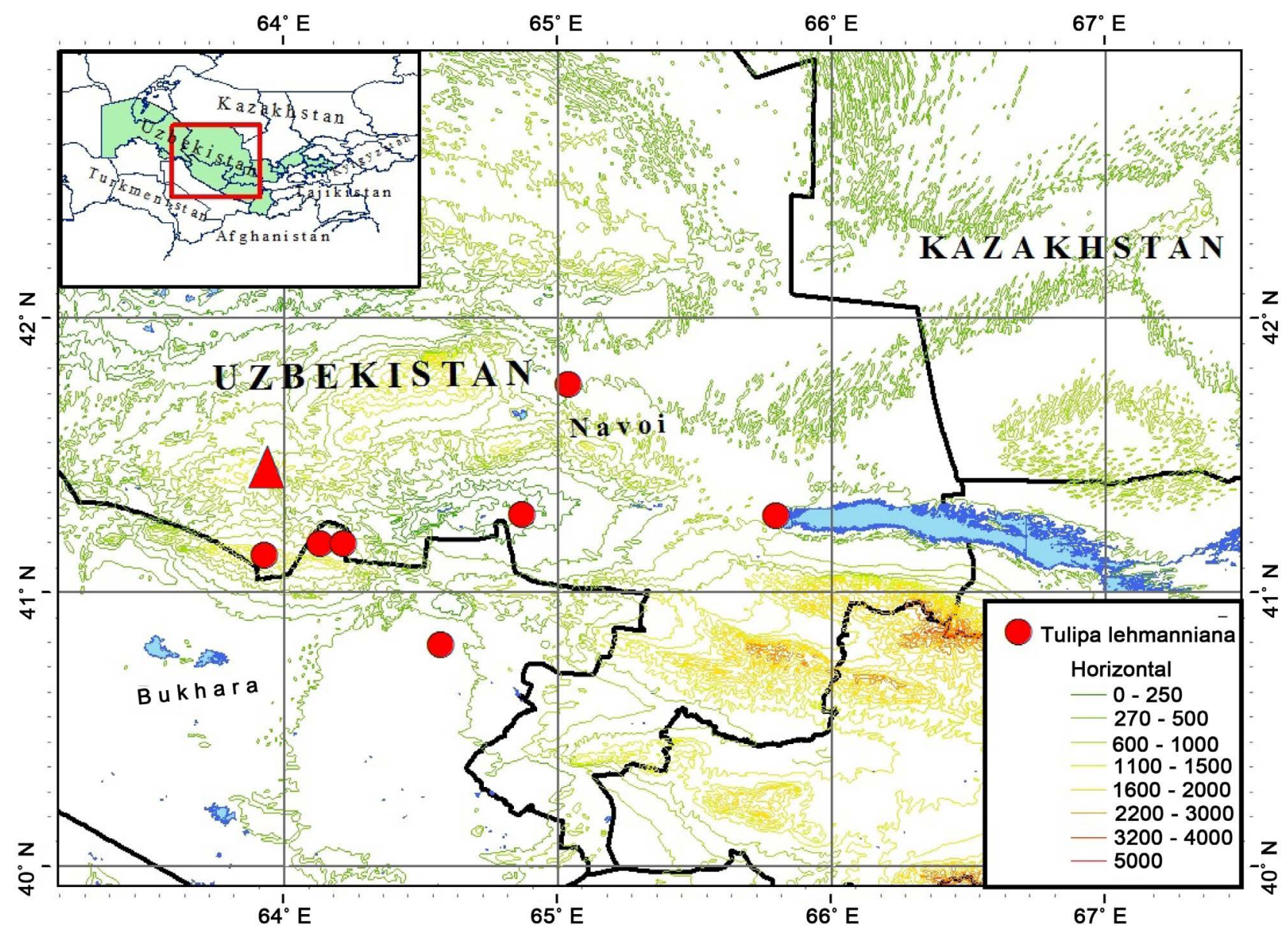

Figure 3. Schematic map of the study area. $\mathbf{\Delta}$-optimal coenopopulation; $\bullet$-pessimal coenopopulation.

\section{Acknowledgements}

The current research is done under the project FA-A7-T005 "Assessment of coenopopulations state of rare and endangered species on the low mountains of Kyzylkum desert”.

\section{References}

[1] Vvedensky, A.I. and Kovalevskaya, S. (1971) Genus of Tulipa L. of Plants of Central Asia. Tashkent. Fan, 2, 94-109.

[2] Abduraimov, O.S. and Shomurodov, H.F. (2015) The Ontogenesis and Ontogenetic Structure of Tulipa micheliana Th. Hoog (Liliaceae) Coenotic Populations in Uzbekistan, UAE. Journal of Novel Applied Sciences, 4, 1089-1096.

[3] Tojibaev, K.Sh. and Qodirov, R.U. (2010) Tulips of Uzbekistan. Tashkent, Sharq, 224.

[4] Red Book of Uzbekistan (2009) Plants and Fungi. Chinor Publishing House, Tashkent, Vol. 1, 356.

[5] Vvedensky, A.I. (1971) Determinant Plants of Central Asia. V. II. - Tashkent: Fan. 102.

[6] USSR Academy of Sciences (1935) Flora of the USSR. V.IV. 341.

[7] Uranov, A.A. (1975) Age Spectrum of Phytocoeno-Population as a Function of Time and Energy Wave Processes. Scientific Lectures of Higher Schools, Biological 
Sciences, No. 2, 7-34.

[8] Uranov, A.A. and Serebryakova, T.I. (1976) Coenopopulations of Plants 1976 (Basic Concepts and Structure). Nauka, Moscow, 216.

[9] Zaugolnova, L.B. (1994) The Structure of the Populations of Seed Plants and Monitoring. Resume of Dissertation of Doctor of Biological Sciences, St. Petersburg, 70.

[10] Uranov, A.A. and Smirnova, O.V. (1969) Classification and Main Features of Development of Populations of Perennial Plants. Bulletin of Moscow Society of Naturalists (Department of Biology), 2, 119-134.

[11] Jivotovsky, L.A. (2001) Ontogenetic States, Effective Density and Classification of Plant Populations. Russian Journal of Ecology, 32, 3-7.

[12] Odum, U. (1986) Ecological Density of Individuals. Ecology, 2, 209.

[13] Markov, M.V. and Pleschinskaya, E.N. (1987) Reproductive Effort in Plants. Journal of General Biology, 48, 77-82.

[14] Ishbirdin, A.R. and Ishmuratova, M.M. (2004) By the Estimation of Vitality Cenopopulation Rhodiola iremelica Boriss for Dimensional Spectrum. Nijniy Tagil, 80-85.

[15] Lavrenko, E.M. and Korchagina A.A. (1972) Field Geobotany. Academy Sciences SSSR, Leningrad, Vol. 4, 336.

[16] Czerepanov, S.K. (1995) Vascular Plants of Russia and Adjacent States (The Former USSR). Cambridge University Press, New York, 152.

\section{Submit or recommend next manuscript to SCIRP and we will provide best} service for you:

Accepting pre-submission inquiries through Email, Facebook, LinkedIn, Twitter, etc. A wide selection of journals (inclusive of 9 subjects, more than 200 journals)

Providing 24-hour high-quality service

User-friendly online submission system

Fair and swift peer-review system

Efficient typesetting and proofreading procedure

Display of the result of downloads and visits, as well as the number of cited articles

Maximum dissemination of your research work

Submit your manuscript at: http://papersubmission.scirp.org/

Or contact ajps@scirp.org 